\author{
ERNEST BARIĆ \\ (Pečuh, Mađarska)
}

\title{
Jadranka Mlikota - Ana Lehocki-Samardžić: Mađarska sastavnica hrvatske gramatikografije 19. stoljeća, Filozofski fakultet Osijek i Hrvatska sveučilišna naklada, Zagreb, 2021. 335. str.
}

Izvorna znastvena monografija $\mathrm{s}$ jasno razdvojenim dvjema tematskim cjelinama. U prvoj su predstavljeni prekogranični jezikoslovci druge polovice 19. stoljeća i njihova djela i to: Illir Nyelvtan Döme Popovicha, Gyakorlati Ilir Nyelvtan Ivana Mihálovića - prinos mađarskoj sastavnici hrvatske jezikoslovne povijesti, Gramatički priručnici Ivana Mihalovića, Horvát Nyelvtan Józsefa Margitaija, Sinonimičnost u tekstovima Horvát Nyelvtan Józsefa Margitaija, Horvát Nyelvtan Aladára Ehrenhöfera i Rókusa Vidovicsa, Horvát Nyelvtan Aladára Ehrenhöfera i Rókusa Vidovics - prinos hrvatskoj gramatikografiji 19. stoljeća, Jezik administrativno-poslovnih tekstova u gramatičkom priručniku Ehrenhöfera i Vidovicsa Horvát Nyelvtan. Druga tematska cjelina tematizira hrvatsko-mađarska nazivoslovna i onomastička prožimanja sa sljedećim podnaslovima: Hrvatsko gramatičko nazivlje u priručnicima ugarskoga dijela Podunavlja druge polovine 19. stoljeća. Vlastita imena u gramatikama hrvatskoga jezika u Mađarskoj. Onimi u gramatikama hrvatskoga na mađarskom jeziku druge polovice 19. stoljeća. Svi tekstovi se međusobno nadopunjavaju i zajedno čine cjelinu mađarske sastojnice hrvatske gramatikografije druge polovice 19. stoljeća. Budući da se radi o potpuno neistraženom jezikoslovnom području mađarsko-hrvatskog prožimanja, za razliku od otprije poznatih njemačkih, talijanskih i latinskih sastavnica hrvatskoga jezikoslovlja, autorice u ovom svom djelu na temelju pouzdanog poznavanja mađarskoga jezika i prilika u mađarskom jezikoslovlju opisuju mađarsku sastavnicu hrvatske gramatikografije u 19. stoljeću. S obzirom da su hrvatska jezikoslovna istraživanja poprilično omeđena i zatvorena domaćim granicama, ova knjiga predstavlja iskorak objavljivanjem gramatičkih priručnika hrvatskoga jezika na mađarskom jeziku koji su objavljeni izvan granica Trojednice, u ugarskom dijelu Podunavlja u 19. stoljeću. Autorice su objavile djelo, mađarsku sastavnicu hrvatske gramatikografije u 19. stoljeću o kojoj ni struka ni novija jezikoslovna filologija do danas ništa nije zapisala. Cilj je autorica bio ne samo popisati i opisati gramatičke priručnike hrvatskoga jezika na mađarskom jeziku u drugoj polovici 19. stoljeća već utvrditi i povezanost prekograničnih autora sa stanjem u Trojednici te utvrditi i druge (europske) utjecaje na gramatičke priručnike. Kao plod temeljitog istraživačkog rada nastalih zadnjih godina objavljeni su radovi u domaćim i inozemnim 
znanstvenim zbornicima i časopisima koje dijelom autorice donose i u ovoj knjizi. Dakako u knjizi su i nova, dosada neobjavljena istraživanja o prekograničnim autorima koji su svojim gramatikografskim radom pridonijeli objema filologijama i hrvatskoj i mađarskoj. Pošto su se u Hrvatskoj nakon osamostaljenja i demokratskih promjena intenzivirala istraživanja o povijesti hrvatskoga jezika u 19.stoljeća i nastala značajna djela, nažalost što zbog ranijega prešućivanja što zbog nepoznavanja mađarskoga jezika mađarska sastavnica hrvatske gramatikografije i hrvatsko-mađarskih jezikoslovnih prožimanja ostali su izvan interesa hrvatskih jezikoslovaca. Otuda osim nekoliko tekstova iz pera mađarskih kroatista na hrvatskom jeziku ova je tema takoreći u cijelosti nepoznata hrvatskoj jezikoslovnoj zajednici, stoga ova knjiga svojim sadržajem a rađena znanstvenom akribijom uvelike može pridonijeti upotpunjavanju slike o sudbini i stanju hrvatskoga jezika izvan hrvatskih granica u 19. stoljeću.

Monografija je namijenjena primarno stručnoj javnosti, ali i studentima hungarologije u Hrvatskoj i studentima kroatistike u Mađarskoj budući da mađarska sastavnica hrvatske gramatikografije do sada nije bila obrađena ni ugrađena u hrvatsku jezičnu povijest. Knjigu čine kao što rekoh dva tematska bloka. Prvim Gramatikografski prinosi, obuhvaćeni su prekogranični autori gramatika kojima je uz mađarski kao metajezik zajedničko mjesto objavljivanja - ugarski dio Podunavlja - te jezik koji opisuje hrvatski, a možemo jednosmisleno utvrditi pripadnost tih gramatika zagrebačkoj filološkoj školi. Drugi tematski blok - Hrvatsko-mađarska nazivoslovna i onomastička prožimanja ostaje građom u okvirima gramatičkih priručnika prekograničnih autora, no u njemu je istraživački pogled usmjeren gramatičkom nazivlju imena, i to s kontaktološkoga i kontrastivnoga aspekta, čime su se priručnici potvrdili kao vrelo ne samo gramatikografskih već i šire jezikoslovnih proučavanja. U svakom slučaju knjiga je vrlo poticajna za upotpunjavanju slike jezikoslovnoga stanja hrvatskoga jezika i izvan hrvatskim granicama omeđenoga prostora.

Knjiga je pisana jasno, pregledno i konzistentno, pisana je uobičajenim znanstvenim diskursom. Podaci iznijeti u tekstu su provjereni, oprimjereni i provjerljivi. Autorice su pokazale da odlično poznaju literaturu iz općega jezikoslovlja, slavistike i kroatistike, što potvrđuje i preko stotinu bibliografskih jedinica. Konzultirale su svu relevantnu literaturu o predmetu o kojem pišu. Kada je riječ o uzorima konzultirale su rječnike, mrežne izvore, novine i časopise. Pokazale su zavidnu upućenost u sve izvore u Mađarskoj koje su temeljito obradile. Tabelarna oprimjerivanja, komparativna prikazivanja podudarnosti i razlika u pristupu pojedinih slovničara u znatnoj mjeri pridonose preglednosti i lakšem sagledavanju stavova pojedinih autora. Jednako tako autorice su pokazale također da dobro poznaju i suvremena kretanja u jezikoslovlju kada je riječ o temi kojom se bave.

Ova monografija cjelovito obrađuje, koristeći suvremenu metodologiju, mađarsku sastavnicu hrvatske gramatikografije 19. stoljeća, koja je sasvim do 
sada bila potpuno nepoznata i neproučavana u hrvatskom jezikoslovlju. Budući da je riječ o složenoj problematici, autorice pomnim proučavanjem djelatnosti mađarskih autora hrvatskih gramatika na mađarskom jeziku na pregledan način, služeći se tablicama, komparativnom analizom, citiranjem relevantne literature, preciznim iznošenjem podataka pokazuju da su paralelno s hrvatskim gramatikama u Hrvatskoj nastale hrvatske gramatike i izvan Hrvatske u Mađarskoj na mađarskom jeziku te da su autori tih gramatika bili u kontaktu s predstavnicima Zagrebačke filološke škole. Posebno je zanimljivo da su pobjedom vukovaca u Hrvatskoj mađarske gramatike hrvatskoga jezika još neko vrijeme čuvale tradiciju Zagrebačke filološke škole. Zahvaljujući ovome rukopisu, na jednom mjestu imamo sve relevantne podatke o raznim aspektima hrvatskih gramatika na mađarskom jeziku a time i cjelovitiju sliku o hrvatskoj gramatikografiji u 19. stoljeću. Knjiga predstavlja vrijedan doprinos cjelovitosti razvoja hrvatskoga jezika u 19. stoljeću. Sve obrađene gramatike hrvatskoga jezika na mađarskom jeziku izvan Trojednice jednosmisleno pokazuju povezanost njihovih uglednih autora s predstavnicima i načelima Zagrebačke filološke škole. Gramatika Döme Popovicha (1863.) svejedoči o vrhunskom poznavanju hrvatskoga leksičkoga blaga njezina autora, i zbog dubleta je nešto više opisna, manje normativna. Popovich dobro poznaje djelatnost Vuka Stefanovića Karadžića no ne prihvaća ga kao normizatora hrvatskoga jezika. Ivan Mihalović (1874.) kao istaknuti bajski preporoditelj svojim je jezikoslovnim, gramatičkim, rječničkim priručnicima te brojnim prijevodnim čitankama popunio prazninu koja je nakon dualističkoga uređenja Habsburškoga Carstva postojala u hrvatskim školama u ugarskom dijelu Podunavlja. Mihalović je baštinio jezična obilježja Zagrebačke filološke škole. Valja napomenuti i to da se za njegovo ime vezuje i prvenstvo napuštanja dvoslova „er“ za slogotvorni (r) a ne Vebera kako se dosada mislilo. Horvát Nyelvtan Józsefa Margitaija (1885.) sa svoja 4 izdanja brojnošću nadilazi sve gramatike hrvatskoga jezika pisanih na mađarskom jeziku. Istaknuo se jasnim lučenjem hrvatskoga od srpskoga jezika, poziva se na sve suvremene hrvatske slovničare, ukazuje na međimursku kajkavštinu, tipičan predstavnik Zagrebačke filološke škole i u vrijeme kada je hrvatsko jezikoslovje pod kraj stoljeća krenula Vukovim putem. Sociopolitički razlozi koji su potaknuli jezične promjene na hrvatskom tlu neće se odraziti na gramatičke priručnike izvan njenih granica. Margitićevo izvrsno poznavanje leksičkoga blaga hrvatskoga jezika, purističan odnos prema tom jeziku dolaze do izražaja kada daje prednost izvornim hrvatskim leksemima pred posuđenicama. Horvát Nyelvtan Aladára Ehrenhöfera i Rókusa Vidovicsa (1897.) ima jezična obilježja Zagrebačke filološke škole unatoč vremenu u kojem je otisnuta. Ova gramatika kao i sve prethodne nastavljaju tijek razvoja hrvatskoga jezika oslanjajući se na hrvatsku jezičnu tradiciju. Analiza jezika administrativnoposlovnih tekstova uvrštenih u Ehrenhöfer - Vidovicsevu gramatiku potvrdila je sljeđenje gramatičke norme i veliku jezično-stilsku podudarnost s hrvatskim gramatikama na području Trojednice. Odstupanja su rubna. 
Analiza prezimena i toponima u gramatikama na mađarskom jeziku je pokazala da imenska građa u njima ne prati stanje u Trojednici. Pripadnici hrvatske zajednice u mađarskom dijelu Monarhije bilježe ih prema prilagođenom mađarskom sistemu pišući ih s dočetkom -ity, -ics ili -its. Analiza imenske građe u hrvatskim gramatikama na mađarskom jeziku ostaju usuprot mađarizaciji, bliže hrvatskoj praksi.

Zaključno valja reći da je knjiga rezultat višegodišnjih istraživanja, ističe se visokim stupnjem izvornosti u pristupu, obradi i analizi prezentirane građe te predstavlja iznimno vrijedan doprinost za cjelovito i svestrano prikazivanje jezičnoga razvoja hrvatskoga jezika u drugoj polovici 19. stoljeća. 